\title{
Local tectonic deformations measured by extensometer at the eastern foothills of the Alps at the Sopronbánfalva Geodynamic Observatory, Hungary
}

\author{
Gyula MENTES*, Márta KISZELY
}

Geodetic and Geophysical Institute, Research Centre for Astronomy and Earth Sciences, Hungarian Academy of Sciences,

Csatkai E. u. 6-8, 9400 Sopron, Hungary

\begin{abstract}
In Hungary, at the foot of the Eastern Alps, in the Sopronbánfalva Geodynamic Observatory (SGO), a quartz-tube extensometer has been used for recording the Earth's tides and local tectonic deformations since 1991. The 27-year long strain record (1991-2017) shows a continuous compression of the rock with changing rate. The relations between the measured local deformation and present-day tectonics in the region of the observatory were investigated. The local strain rate variations were also compared with the temporal and spatial distribution as well as with the magnitudes of earthquakes occurred within $200 \mathrm{~km}$ from the observatory in two sectors around the azimuth of the extensometer $\left(116^{\circ}\right): 116^{\circ} \pm 15^{\circ}$ and $296^{\circ} \pm 15^{\circ}$. Our investigations show that earthquakes can also influence the strain rate. Earthquakes to the west of SGO generally increase the compressive strain rate, while earthquakes in the Pannonian Basin, with some exceptions, have no significant effect on the local strain rate variations measured in the SGO. It has been found that the recorded compressive strain is in good accordance with the recent tectonic processes in the region of the SGO determined by Global Navigation Satellite System (GNSS) technology and geophysical measurements. From the results it can be concluded that the uplift of the Alps, tectonic processes in the East Alpine region and in the Pannonian Basin play the most important role in the changing local compressive strain rate.
\end{abstract}

Key words: earthquake; extensometer; tectonic deformation; varying strain rate

\section{Introduction}

Besides the global deformation measurement techniques as the Very Long Baseline Interferometry (VLBI) measurements (e.g. Ward, 1994; Krásná et al., 2013, 2015; Plank et al., 2014), GNSS technology (e.g. Caporali et al.,

\footnotetext{
*corresponding author: tel.: +36-99-508382, e-mail: mentes@ggki.hu
} 
2008, 2009) and the Persistent Scatterer Interferometry Synthetic Aperture Radar (PSInSAR) technique (e.g. Massonnet and Feigl, 1998; Burgmann et al., 2000; Hanssen, 2001) the high resolution extensometric measurements are also used for observation of local tectonic deformations in some observatories (e.g. Sato and Harrison, 1990; Varga and Varga, 1994; Onoue and Takemoto, 1998; Takemoto et al., 2006). GNSS and PSInSAR techniques are also suitable for local deformation measurements, but the temporal and deformation resolution of extensometers are much better than that of the PSInSAR and GNSS technologies. In addition to the tectonic deformations extensometers also record short periodic deformations caused by Earth' tides and the recorded data are influenced by different effects depending on the properties of the instruments and the local conditions of the measurement site (Harrison, 1976; Sato and Harrison, 1990; Venedikov et al., 2006). A large number of authors deal with the influence of the construction and the surroundings of the instrument's site appearing as cavity, topographic and lithologic effects (e.g. Farrell, 1972; Harrison, 1976; Brimich et al., 1998; Gebauer et al., 2009, 2010). The deformations caused by the atmospheric pressure and temperature variations also depend on the properties of the observation site. A lot of publications deal with the effect of atmospheric pressure loading on horizontal deformation measurements (e.g. Müller and Zürn, 1983; Rabbel and Zschau, 1985; Sun et al., 1995; Dal Moro and Zadro, 1998; Kroner et al., 2005; Steffen et al., 2006; Zürn et al., 2007). To obtain real tectonic deformations the above mentioned disturbing effects must be corrected.

In the SGO at the foot of the Eastern Alps a quartz-tube extensometer has been recording local tectonic deformations and Earth' tides since 1991. The strain record shows a compression with varying rate. In this paper the relationships between the measured local strain and recent tectonic processes in the Eastern Alps and in the Pannonian Basin as well as the direct effect of earthquakes on the strain rate variations are investigated.

\section{Observation site and the instrument}

The SGO is located in the Sopron Mountains which belong to the extensions of the Eastern Alps (Alpokalja region). The Sopron Mountains consist of metamorphic rocks of Palaeozoic age such as gneiss and different mica schists 
(Haas, 2001). The observatory is an artificial gallery driven into an outcrop of the muscovite gneiss (Kisházi and Ivancsics, 1985). The rock cover above the observatory is about $60 \mathrm{~m}$. The location of the SGO and the main faults (Sikhegyi, 2002; Brückl et al., 2010) in the region of the observatory are shown in the Fig. 1. The coordinates of the SGO are $47^{\circ} 40^{\prime} 55^{\prime \prime} \mathrm{N}$, $16^{\circ} 33^{\prime} 32^{\prime \prime} \mathrm{E}$ and it is $280 \mathrm{~m}$ a.s.l. The observatory and its surroundings are described by Mentes (2012) in detail.

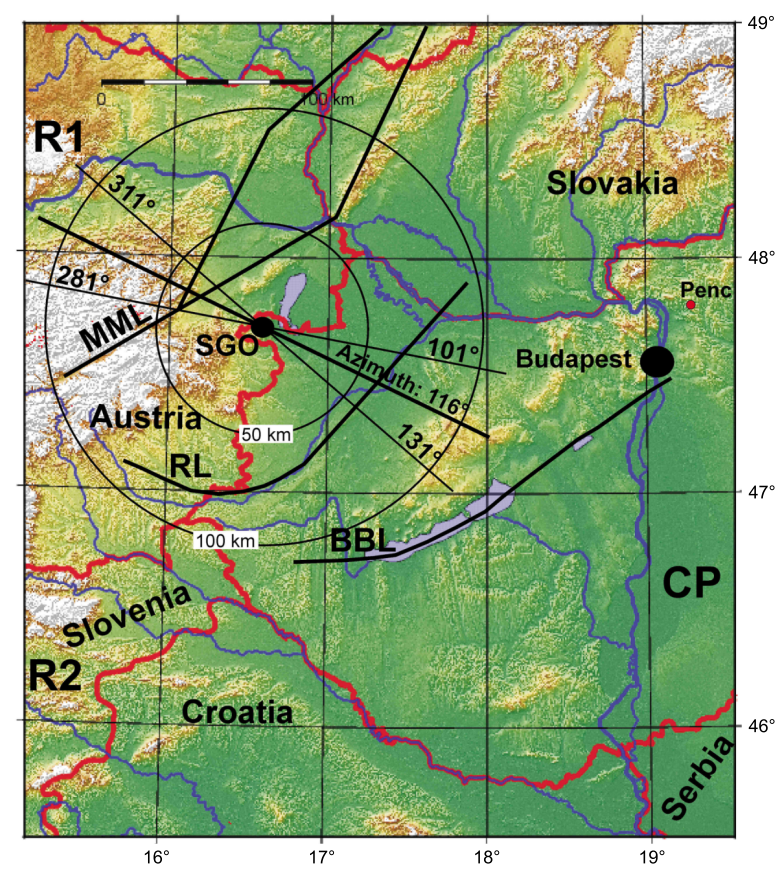

Fig. 1. Location of the SGO and the main faults in its region. MML, RL, BBL are the Mur-Mürz, Rába, and the Balaton-Bodrog lines, respectively. R1, R2 and CP are the regions where the recent tectonic rates were investigated on the basis of GPS data.

The temperature in the gallery, where the extensometer is placed, is very stable. Its yearly mean value is $10.4^{\circ} \mathrm{C}$ and the yearly and daily temperature variations are less than $0.5^{\circ} \mathrm{C}$ and $0.05{ }^{\circ} \mathrm{C}$, respectively, therefore the direct effect of temperature on the instrument is negligible. Temperature and air pressure variations cause rock strain variations at the site and in the surroundings of the observatory that interfere with tidal and tectonic deformations, and therefore need to be corrected (Mentes, 2000, 2012). 
The quartz-tube extensometer with a capacitive sensor has a length of $22 \mathrm{~m}$. Its azimuth is $116^{\circ}$ so it is nearly perpendicular to the main fault system in its surroundings (Fig. 1). A built-in magnetostrictive actuator is used for regular calibration of the instrument. The soundness of the quartz tube and the stability of the scale factor of the extensometer are checked once a day by the built-in calibrator. Since the parameters of the magnetostrictive actuator may also change, the extensometer is yearly calibrated by means of a portable calibrator which is calibrated by a laser interferometer in the laboratory of the institute before and after of the in-situ calibration of the extensometer in the observatory. The scale factor of the extensometer is $2.093 \pm 0.032 \mathrm{~nm} \mathrm{mV}^{-1}$ or $0.095 \pm 0.001 \mathrm{nstr} \mathrm{mV}^{-1}\left(1 \mathrm{nstr}=10^{-9}\right.$ relative extension $=$ measured displacement/length of the extensometer). The error of the yearly calibrations and the amplitude variations of the daily calibration impulses are within the error range of the scale factor determination. Mentes (2010) describes the construction and calibration of the instrument in detail.

\section{Seismicity of the investigated region}

The Carpathian Basin is situated in the territory between the Mediterranean area - which is seismically one of the active regions - and the Carpathian Mountains belt. The area is tectonically rather complicated, and the distribution of earthquake epicentres shows a rather scattered pattern (Bus et al., 2009). The most active seismic regions near to the SGO are the Mur-Mürz and the Central Pannonian zones (see Fig. 1). The Mur-Mürz zone running from Mura valley to the western Carpathians is the junction of the Eastern Alps and the Pannonian Basin. The tectonics of the Pannonian Basin is caused fundamentally by the northward movement and counter clockwise rotation of the Adria microplate also known as the "Adria-push". Due to ongoing convergence between the European Plate from the north and the Adriatic plate from the south, crustal blocks extrude laterally to the east into the Pannonian Basin (Brückl et al., 2010; Caporali, 2009; Bada et al., 2007a,b; Decker et al., 2005; Fodor et al., 2005).

Focal mechanism results in the Pannonian Basin are more diverse although thrust and strike-slip faulting seem to be dominant. NNE-SSW 
and NE-SW directions of maximum horizontal stresses are prevailing. The focal mechanism findings in the Eastern Alps show that the majority of the tectonic movements have strike-slip mechanisms with NNW-SSE and NS directions, but NE-SW directions are nonetheless occasionally observed (Bada et al., 2007a; Tóth et al., 2008; Olaiz et al., 2009).

The seismicity of an area can be characterized by the number of earthquakes, their magnitudes and the spatial location of earthquakes and by the released energy. Fig. 2 shows the epicentre map of earthquakes around the SGO between the coordinates $45.5^{\circ} \mathrm{N}, 13.5^{\circ} \mathrm{E}-49.5^{\circ} \mathrm{N}, 19.5^{\circ} \mathrm{E}$ from 1991 to 2017

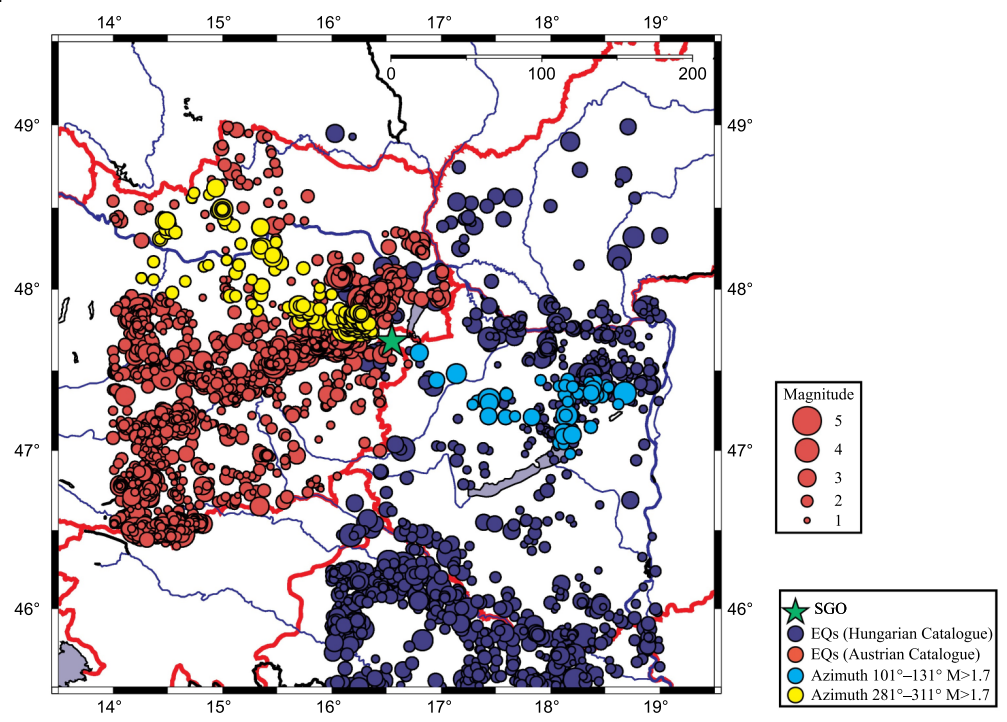

Fig. 2. The seismicity map around the SGO (green star) between the years 1991 and 2017 (Tóth et al., 1996-2018; Gráczer et al., 2012-2016; ZAMG, 2018).

\section{Methods and data processing}

Since the extensometer is also used for tidal monitoring, the stability of the instrument can also be demonstrated by the stability of the measured tidal parameters. Yearly measured extensometric data were corrected for temperature and barometric pressure and then subjected to tidal analysis using the ETERNA 3.40 tidal processing program package (Wenzel, 1996). The tidal processing of the data is described by Mentes (2012) and Bán 
et al. (2018) in detail. While the calibration only provides information on the stability of the instrument, the amplitude factors (measured/theoretical amplitudes) for the main lunar diurnal O1 and the semidiurnal M2 waves were used to check the stability of the attachment of the extensometer to the rock and the state of the rock in the vicinity of the instrument. The obtained average value of the yearly determined $\mathrm{O} 1(0.65 \pm 0.07)$ and M2 $(1.08 \pm 0.11)$ tidal factors show clearly that the fixation of the instrument to the rock and the properties of the rock in the vicinity of the observatory did not change during the registration period.

The "drift" remaining after the correction of the extensometric raw data for seasonal effects can be assumed as tectonic movement and deformation. For investigation of the long-term tectonic movements, the annual raw data were concatenated into a 27 -year long data series. A polynomial of 9 th order was fitted to the long strain data series to eliminate the short periodic and seasonal variations.

The temporal and spatial distribution of seismicity was investigated around the SGO up to $200 \mathrm{~km}$ distance. For that purpose, we used the data of the Hungarian Earthquake Bulletins ranging in time from 1995 to 2017 (Tóth et al., 1996-2018; Gráczer et al., 2012-2016), which are the most complete catalogues for the smallest events between the $45.5^{\circ}-49.5^{\circ} \mathrm{N}$ $16^{\circ}-23^{\circ}$ E territory. For western and northern side of the investigated regions we used the Austrian Earthquake Catalogue $(Z A M G$, 2018). Since the extensometer is sensitive to displacements in its azimuth, firstly we examined the seismicity of this region in two $30^{\circ}$ wide sectors around the SGO. The centre azimuths of the sectors were $116^{\circ}$ and $296^{\circ}$. The number of earthquakes (EQs), and the released energy for different distances from the SGO were determined. The energy of EQs was calculated according to Gutenberg and Richter (1942). The number of earthquakes and the released energy are both very important features of an area. If energy is only taken into account, the largest few EQs will be only emphasized, without the yearly variation of seismicity. If we ignore the energy, the annual number of the EQs presents mainly the development of the seismological station network or the aftershocks sequences. We have chosen a magnitude threshold $\mathrm{M} \geq 1.7$ because earthquakes of this magnitude were already reliably recorded 30 years ago. We expected that the yearly number of these EQs mirrors mainly the changing of the seismicity. 


\section{Results}

\subsection{Results of the extensometric measurements}

The Fig. 3 shows both the measured "raw" strain data and the fitted polynomial between 1991 and 2017. We also calculated the yearly average strain rates by fitting a line to the yearly extensometric data (Fig. 4a). It can be seen that the compressive strain rate is increasing rapidly between 1993 and 2001, then rate has slowed down and from 2014 it is less than $2 \mu$ str $^{-1}$.

\subsection{Results of the investigation of the earthquakes' effects}

The seismicity of the two $30^{\circ}$ wide sectors $\left(116^{\circ} \pm 15^{\circ}, 296^{\circ} \pm 15^{\circ}\right)$ around the SGO was different both in activity and yearly variations. The activity is partly reflected by the number of events and the released energy. Table 1 contains the number of EQs, and the released energy for different distances from the SGO. The $116^{\circ} \pm 15^{\circ}$ sector was more active than the opposite $\left(296^{\circ} \pm 15^{\circ}\right)$ since there occurred about twice as many earthquakes of $\mathrm{M} \geq$ 0.1 . In the sector of $296^{\circ} \pm 15^{\circ}$ up to $200 \mathrm{~km}$ distance there occurred about three times more earthquakes of $\mathrm{M} \geq 1.7$ than in the $116^{\circ} \pm 15^{\circ}$ sector. But within $100 \mathrm{~km}$ from the SGO, there were twelve times more earthquakes of $\mathrm{M} \geq 1.7$ in the $296^{\circ} \pm 15^{\circ}$ sector than in the opposite. The released

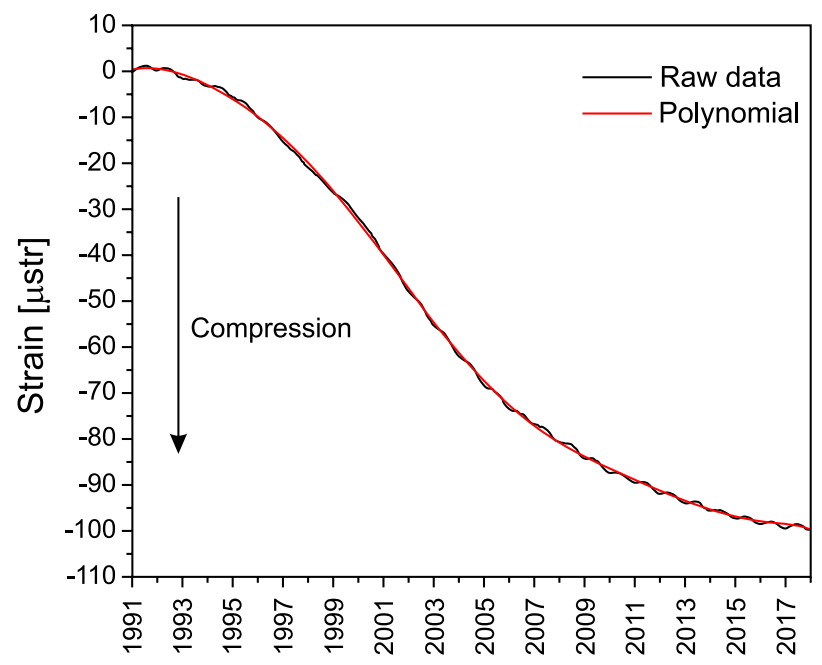

Fig. 3. Rock strain measured in the SGO between 1991 and 2017. 
energy by earthquakes was almost four times more up to $200 \mathrm{~km}$ distance around the SGO, and within $100 \mathrm{~km}$ was ten times more in the $296^{\circ} \pm 15^{\circ}$ sector than in the opposite. The Figs. $4 \mathrm{~b}-\mathrm{g}$ show the smoothed number and the total and smoothed energy of EQs. The smoothed values are the three year moving average of the number and energy of EQs. The Fig. $4 \mathrm{~b}$ shows the yearly distribution of EQs $\mathrm{M} \geq 1.7$ in the sector $116^{\circ} \pm 15^{\circ}$ and Fig. 4 c shows the released energy of EQs $M \geq 1.7$ within $R=200 \mathrm{~km}$ from the SGO. Figs. $4 \mathrm{~d}-\mathrm{e}$ show the yearly distributions of earthquakes and the released energy for the opposite side. Since the extensometer is sensitive to displacement in its azimuth we also investigated the effect of EQs in a narrow sector around its azimuth $\left(116^{\circ} \pm 4^{\circ}\right.$ and $296^{\circ} \pm 4^{\circ}$ and within $30 \mathrm{~km}$ distance from the SGO. The Figs. $4 \mathrm{f}-\mathrm{g}$ show the number of EQs and the released energy. It can be seen that some active years occurred in both sectors in the 27 -year observational period. The sector $296^{\circ} \pm 4^{\circ}$ up to $30 \mathrm{~km}$ distance around the SGO was more active than the opposite side.

Table 1. The seismicity of the investigated area around the SGO.

\begin{tabular}{|c|c|c|c|c|}
\hline Investigated area & $\begin{array}{l}\text { Number } \\
\text { of EQs } \\
M \geq 0.1\end{array}$ & $\begin{array}{c}\text { Number } \\
\text { of EQs } \\
M \geq 1.7\end{array}$ & $\begin{array}{c}\text { Max. } \\
\text { Richter } \\
\text { magnitude }\end{array}$ & $\begin{array}{c}\text { Energy of } \\
\text { EQs } M \geq 0.1 \\
{[\mathrm{GJ}]}\end{array}$ \\
\hline $\begin{array}{l}\text { within } 200 \mathrm{~km} \text { from } \mathrm{SGO} \text { and } \\
\text { between azimuths: } 101^{\circ}<116^{\circ}<131^{\circ}\end{array}$ & 558 & 50 & 3.7 & 60.4 \\
\hline $\begin{array}{l}\text { within } 100 \mathrm{~km} \text { from } \mathrm{SGO} \text { and } \\
\text { between azimuths: } 101^{\circ}<116^{\circ}<131^{\circ}\end{array}$ & 28 & 10 & 3.5 & 18.4 \\
\hline $\begin{array}{l}\text { within } 200 \mathrm{~km} \text { from } \mathrm{SGO} \text { and } \\
\text { between azimuths: } 281^{\circ}<296^{\circ}<310^{\circ}\end{array}$ & 379 & 168 & 4.0 & 229.2 \\
\hline $\begin{array}{l}\text { within } 100 \mathrm{~km} \text { from } \mathrm{SGO} \text { and } \\
\text { between azimuths: } 281^{\circ}<296^{\circ}<310^{\circ}\end{array}$ & 282 & 120 & 4.0 & 203.8 \\
\hline
\end{tabular}

For investigation of the effect of EQs on the strain rate variation, the number and the released energy of EQs were compared to the strain rate. Despite the limited number of data (27) in the data series, correlation analysis was performed between strain rate data and the number and energy of EQs in each sector. Results are shown in Table 2. On the one hand the obtained small correlation coefficients cannot be considered to be significant (less than 0.7) due to the small number of data. On the other hand, they suggest that the direct effect of earthquakes on strain rate changes is less 

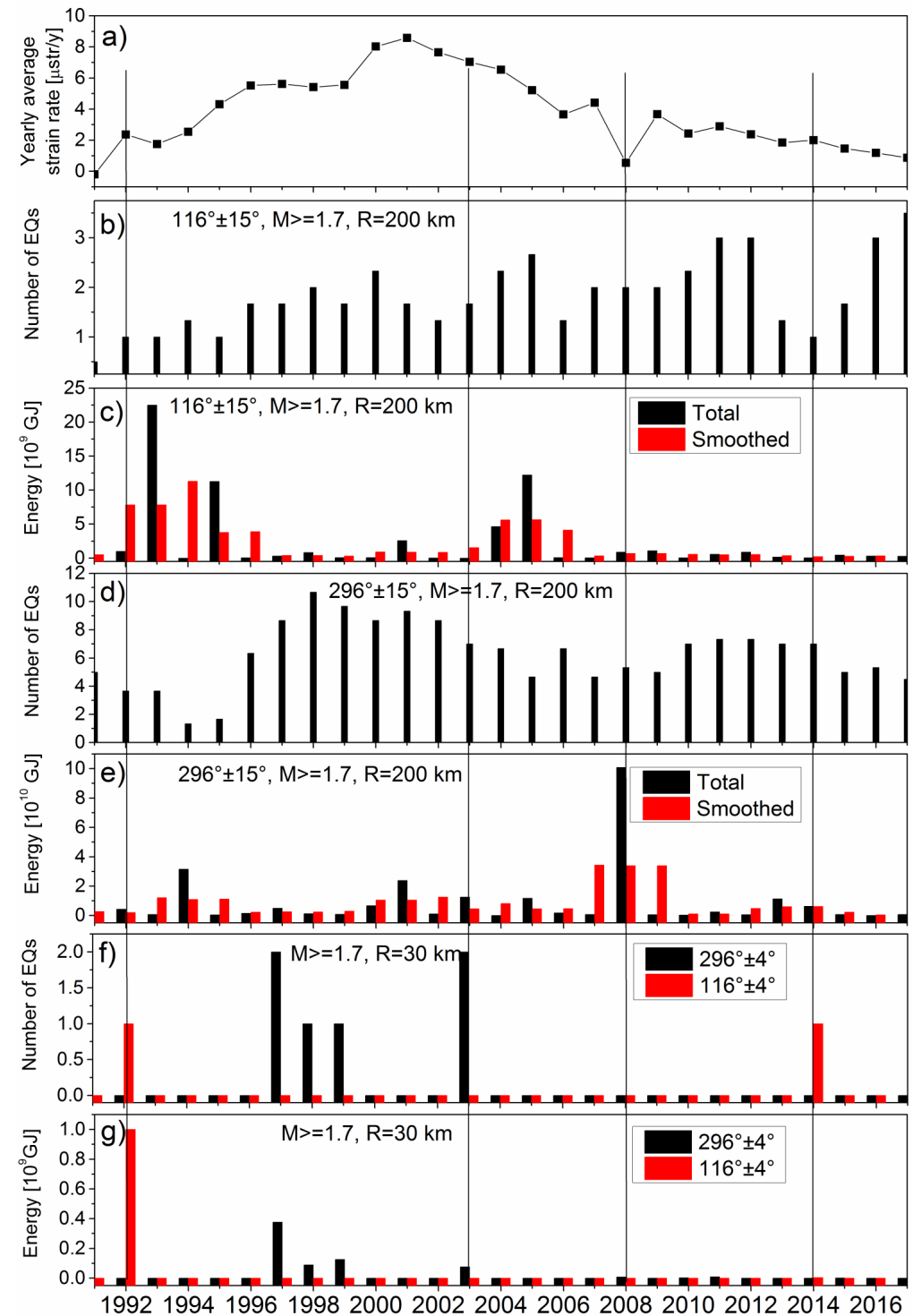

Fig. 4. Yearly strain rates (a), smoothed number (b) and energy of earthquakes (c) within $200 \mathrm{~km}$ from the SGO in the sector $116^{\circ} \pm 15^{\circ}$, smoothed number (d) and energy of earthquakes (e) within $200 \mathrm{~km}$ from the SGO in the sector $296^{\circ} \pm 15^{\circ}$, number (f) and energy $(\mathrm{g})$ of earthquakes within $30 \mathrm{~km}$ from the SGO in the sectors $116^{\circ} \pm 4^{\circ}$ and $296^{\circ} \pm 4^{\circ}$. 
than that of other tectonic processes in the region. The correlation coefficients between the strain rate and the number and energy of EQs in the $296^{\circ}$ sector $\left(296 \pm 15^{\circ}\right.$ and $\left.296 \pm 4^{\circ}\right)$ are only between 0.20 and 0.53 . The sign of the coefficients in the $296^{\circ}$ sector is positive, while in the $116^{\circ}$ sector is negative. Despite the small correlation coefficients, these results suggest that earthquakes in the 296 sector generally increase, while in sector 116 they reduce the rate of compression. Practically the same results were obtained when the numbers and energies of EQs in the sector $116^{\circ}$ were subtracted from the same values in the sector $296^{\circ}$ and these differences were correlated with the strain rate (see Table 2). However, the Fig. 4 also shows some opposite examples. In these cases, we can assume that the earthquakes had a direct effect on the rate of compression. The number of EQs and the released earthquake energy in the $116^{\circ} \pm 15^{\circ}\left(116^{\circ} \pm 4^{\circ}\right)$ sector increase the strain rate (see years 1992 and 2014 in the Fig. 4a,f-g) while in the opposite sector decrease it (see years 2003, 2008 in the Fig. 4a,f).

Table 2. Correlation coefficients between strain rate and the number $(\mathrm{N})$ and energies $(\mathrm{TE}=$ total energy and $\mathrm{SE}=$ smoothed energy) of earthquakes in the different sectors.

\begin{tabular}{|c|c|c|c|c|c|c|c|c|c|c|c|c|c|c|c|}
\hline & \multicolumn{10}{|c|}{ Sectors } & \multicolumn{5}{|c|}{ Differences: S269-S116 } \\
\hline & \multicolumn{3}{|c|}{$116 \pm 15^{\circ}$} & \multicolumn{3}{|c|}{$296 \pm 15^{\circ}$} & \multicolumn{2}{|c|}{$116 \pm 4^{\circ}$} & \multicolumn{2}{|c|}{$296 \pm 4^{\circ}$} & \multicolumn{3}{|c|}{ $\pm 15^{\circ}$} & \multicolumn{2}{|c|}{ $\pm 4^{\circ}$} \\
\hline & $\mathrm{N}$ & $\mathrm{TE}$ & $\mathrm{SE}$ & $\mathrm{N}$ & $\mathrm{TE}$ & $\mathrm{SE}$ & $\mathrm{N}$ & $\mathrm{SE}$ & $\mathrm{N}$ & $\mathrm{SE}$ & $\mathrm{N}$ & $\mathrm{TE}$ & $\mathrm{SE}$ & $\mathrm{N}$ & $\mathrm{SE}$ \\
\hline $\begin{array}{l}\text { Corr. } \\
\text { coeff. }\end{array}$ & 0.00 & -0.02 & -0.02 & 0.53 & -0.16 & -0.03 & -0.19 & -0.12 & 0.36 & 0.25 & 0.53 & -0.15 & 0.03 & 0.40 & 0.20 \\
\hline
\end{tabular}

\section{Discussion}

The measured compression in the SGO is in good accordance with the GPS (Global position System) measurements in the Central European GPS Reference Network (CEGRN) (Grenerczy et al., 2000, 2005; Caporali et al., 2008). Strain rates from GPS data (from 1994 to 1998) in the CEGRN and in the Hungarian GPS Geodynamic Reference Network (HGRN) were determined in surroundings of the SGO (Grenerczy et al., 2000). In the region $\mathrm{R} 1$ contraction with a strain rate of $-8.6 \pm 2.5 \mathrm{nstr}^{-1}$ in the $\mathrm{NE}-$ SW direction (see Fig. 1), but in the region R2 a NW-SE compression of $-8.0 \pm 5.3 \mathrm{nstr}^{-1}$ was obtained (see also Tesauro et al., 2006). Bus et al. (2009) determined a principal compressive strain rate $-4.1 \mathrm{nstr}^{-1}$ 
with a NEE-SWW direction in the Central Pannonian (CP) area from the HGRN data from 1991 to 2007 (see also Caporali et al., 2009). In the MurMürz (MM) zone, parallel with the fault $-12 \mathrm{nstr}^{-1}$ compression, while perpendicular to it $9.6 \mathrm{nstr}^{-1}$ extension was obtained (Fodor et al., 2005). These directions correspond to forces moving the East Alpine-North Pannonian unit to the east, rotating it clockwise and the anticlockwise motion of the Adria microplate, causing compression in the Eastern Alps (Caporali and Martin, 2000; Bada et al., 2007a; Caporali et al., 2008; Sánchez et al., 2018). The results derived from borehole breakout, earthquake focal mechanism (FMS) and overcoring measurements in the vicinity of the MM zone show diverse local maximum compression strain directions (Bada et al., 2007b; Olaiz et al., 2009; Brückl et al., 2010). Some of them are parallel with the extensometer in the SGO. Thus we can assume that the direction of the extensometer is near to the direction of the principal compressive strain rate in this local region (see also Olaiz et al., 2009; Bokelmann et al., 2013). Sánchez et al. (2018) investigated the surface deformation of the Alpine region on the basis of GPS measurements. According to their results the deformation vectors in the Eastern Alps describe a progressive eastward rotation towards Pannonia and a shortening in the order of about $1 \mathrm{mmy}^{-1}$. Sternai et al. (2019) found that the uplift rate of the Eastern Alps is about $1 \mathrm{mmy}^{-1}$ characterized by shortening and crustal thickening, which probably can be explained by deglaciation, long-term erosion and dynamic processes related to the sub-lithospheric mantle flow. These processes can cause the ongoing Alpine elevation changes and can be responsible for the high and changing local compressive strain rate measured by the extensometer in the SGO.

The deformation in the Pannonian Basin is not uniform. It is concentrated mostly in the western and central parts of the basin (e.g. Bada et al., 2007a). The vertical movements, such as uplift and subsidence (Horváth and Cloetingh, 1996; Bada et al., 1999) induce horizontal strain (Caporali, 2009). The other reason for the high strain rate measured by the extensometer in the SGO is probably the difference of the vertical velocities in the East Alpine region and in the Pannonian Basin (Cloetingh et al., 2005; Dombrádi et al., 2010). The weak lithosphere (folding and compression) absorbs the strain in the Pannonian Basin (Dombrádi et al., 2010) while faults and earthquakes in the region relax it (Bada et al., 200\%b; Bus et 
al., 2009). Probably, this is the reason for the much smaller strain rates (in the order of nstr $y^{-1}$ ) obtained by GPS measurements in networks with 50-100 km base lines than strain rates (in the order of $\mu$ str $\mathrm{y}^{-1}$ ) measured on short base lines $(1-100 \mathrm{~m})$ by extensometers. Similarly, in other observatories, local strain rates measured by extensometers are also in order of $\mu$ str $^{-1}$ (e.g. Sato and Harrison, 1990; Braitenberg et al., 2001; Brimich, 2006; Takemoto et al., 2006).

Time series measured at individual GPS stations show also daily and seasonal changes, which are also corrected (e.g. Pellegrinelli et al., 2005; Serpelloni et al., 2005; Kontny et al., 2006; Tesauro et al., 2006; Hackl et al., 2011; Bogusz et al., 2012; Rajner and Liwosz, 2017; Sánchez et al., 2018; Sternai et al., 2019) but the change of the rate of tectonic deformations are within the measurement uncertainty of this measurement technology. Therefore, extensometric measurements are still useful in the study of local tectonic deformations.

According to our results the rate of the compression is also affected by EQs in the investigated region of the observatory. A possible explanation that EQs in the sector $116^{\circ} \pm 15^{\circ}$ decrease or do not influence the rate of compression may be that the energy emitted by earthquakes are absorbed by the folding in the Pannonian Basin (Cloetingh et al., 1999; Caporali, 2009; Dombrádi et al., 2010). The released energy by the EQs in the sector $296^{\circ} \pm 15^{\circ}$ contributes to the compressive forces (Bada et al., 200\% et al., 2009; Brückl et al., 2010; Salcher et al., 2012; Bokelmann et al., 2013) in this region of the SGO, increasing the compressive strain rate. In some years, we found that earthquakes had a direct effect on the strain rate changes. However, in these cases their effect on the strain rate is in contrast to what was obtained by the correlation analysis described above.

\section{Conclusions}

The 27-year long strain measurements showed a compressive strain with varying rate at the foot of the Eastern Alps. The measured compressive strain is in good accordance with the GPS and geophysical strain measurements in the region of the SGO. We can assume that the uplift of the Alps, tectonic processes in the East Alpine region and in the Pannonian Basin 
play the most important role in the varying strain rate. This assumption can be proven in the future by measurements in GPS networks with short baselines or by PSInSAR technology, which allows measurement of surface deformations in densely located points.

Our investigations show that earthquakes can also influence the strain rate. Earthquakes to the west of SGO generally increase the compressive strain rate, while earthquakes in the Pannonian Basin, with some exceptions, have no significant effect on the local strain rate variations measured in the SGO.

Based on our measurements, we can assume that in addition to GPS and PSInSAR measurements, continuous, long-term extensometric observations may play a very important role in investigation and understanding of local tectonic movements and deformations in the future.

Acknowledgements. This work was funded by the Hungarian National Research Fund (OTKA) under the project No. K 109060. Special thanks to Tibor Molnár for his careful maintenance of the instruments.

\section{References}

Bada G., Horváth F., Gerner P., Fejes I., 1999: Review of the present day geodynamics of the Pannonian basin: Progress and problems. J. Geodyn., 27, 4-5, 501-527, doi: 10.1016/S0264-3707(98)00013-1.

Bada G., Grenerczy Gy., Tóth L., Horváth F., Stein S., Cloetingh S., Windhoffer G., Fodor L., Pinter N., Fejes I., 2007a: Motion of Adria and ongoing inversion of the Pannonian Basin: Seismicity, GPS velocities and stress transfer. In: S.Stein, S. Mazzotti, (Eds.), Continental Intraplate Earthquakes: Science, Hazard, and Policy Issues. Geological Society of America Special Papers, 425, 16, 243-262, doi : $10.1130 / 2007.2425$ (16).

Bada G., Horváth F., Dövényi P., Szafián P., Windhoffer G., Clothing S., 2007b: Presentday stress field and tectonic inversion in the Pannonian basin. Glob. Planet. Change, 58,1-4, 165-180, doi: 10.1016/j.gloplacha.2007.01.007.

Bán D., Mentes Gy., Kis M., Koppán A., 2018: Observation of the Earth liquid core resonance by extensometers. Pure Appl. Geophys., 175, 5, 1631-1642, doi : 10.1007/ s00024-017-1724-6.

Bogusz J., Figurski M., Kontny B., Grzempowski P., 2012: Horizontal velocity field derived from EPN and ASG-EUPOS satellite data on the example of south-western part of Poland. Acta Geodyn. Geomater., 9, 3, 349-357. 
Bokelmann G., Qorbani E., Bianchi I., 2013: Seismic anisotropy and large-scale deformation of the Eastern Alps. Earth Planet Sci. Lett., 383, 1-6, doi: 10.1016/j.epsl. 2013.09.019.

Braitenberg C., Nagy I., Negusini M., Romagnoli C., Zadro M., Zerbini S., 2001: Geodetic measurements at the northern border of the Adria plate. J. Geodyn., 32, 1-2, 267286, doi : 10.1016/S0264-3707(01)00025-4.

Brimich L., Kohút I., Kostecký P., 1998: Influence of the Cavity Effect on Tidal Measurements. In: Ducarme B., Paquet P., (Eds.): Proceedings of the 13th International Symposium on Earth Tides, Brussels, Observatoire royal de Belgique, pp. 397-412.

Brimich L., 2006: Strain measurements at the Vyhne tidal station. Contrib. Geophys. Geod., Geophysical Institute of the Slovak Academy of Sciences, 36, 4, 361371.

Brückl E., Behm M., Decker K., Grad M., Guterch A., Keller G. R., Thybo H., 2010: Crustal structure and active tectonics in the Eastern Alps. Tectonics, 29, 2, TC2011, doi : 10.1029/2009TC002491.

Burgmann R., Rosen P. A., Fielding E. J., 2000: Synthetic aperture radar interferometry to measure Earth's surface topography and its deformation. Annu. Rev. Earth Planet. Sci., 28, 169-209, doi: 10.1146/annurev .earth.28.1.169.

Bus Z., Grenerczy Gy., Tóth L., Mónus P., 2009: Active crustal deformation in two seismogenic zones of the Pannonian region - GPS versus seismological observations. Tectonophysics, 474,1-2, 343-352, doi: 10.1016/j.tecto.2009.02.045.

Caporali A., 2009: Lithospheric flexure, uplift and expected horizontal strain rate in the Pannonian Carpathian region. Tectonophysics, 474, 1, 337-342, doi: 10.1016/j. tecto.2008.10.033.

Caporali A., Martin S., 2000: First results from GPS measurements on present day Alpine kinematics. J. Geodyn., 30, 1, 275-283, doi : 10.1016/S0264-3707(99) 00037-X.

Caporali A., Aichhorn C., Becker M., Fejes I., Gerhatova L., Ghitau D., Grenerczy G., Hefty J., Krauss S., Medak D., Milev G., Mojzes M., Mulic M., Nardo A., Pesec P., Rus T., Simek J., Sledzinski J., Solaric M., Stangl G., Vespe F., Virág G., Vodopivec F., Zablotskyi F., 2008: Geokinematics of Central Europe: new insights from the CERGOP-2/Environment Project. J. Geodyn., 45, 4-5, 246-256, doi: $10.1016 / j \cdot j o g .2008 .01 .004$.

Caporali A., Aichhorn C., Barlik M., Becker M., Fejes I., Gerhatova L., Ghitau L., Grenerczy Gy., Hefty J., Krauss S., Medak D., Milev G., Mojzes M., Mulic M., Nardo A., Pesec P., Rus T., Simek J., Sledzinski J., Solaric M., Stangl G., Stopar B., Vespe F., Virág G., 2009: Surface kinematics in the Alpine-Carpathian-Dinaric and Balkan region inferred from a new multi-network GPS combination solution. Tectonophysics, 474, 1-2, 295-321, doi: 10.1016/j.tecto.2009.04.035.

Cloetingh S., Burov E., Poliakov A., 1999: Lithosphere folding: Primary response to compression? (from central Asia to Paris basin). Tectonics, 18, 6, 1064-1083, doi: 10.1029/1999TC900040.

Cloetingh S., Maţenco L., Bada G., Dinu C., Mocanu B., 2005: The evolution of the Carpathians-Pannonian system: interaction between neotectonics, deep structure, 
polyphase orogeny and sedimentary basins in a source to sink natural laboratory. Tectonophysics, 410,1-4, 1-14, doi: 10.1016/j.tecto.2005.08.014.

Dal Moro G., Zadro M., 1998: Subsurface deformations induced by rainfall and atmospheric pressure: tilt/strain measurements in the NE Italy seismic area. Earth Planet. Sci. Lett., 164, 1-2, 193-203, doi: 10.1016/S0012-821X (98)00203-9.

Decker K., Peresson H., Hinsch R., 2005: Active tectonics and Quaternary basin formation along the Vienna Basin Transform fault. Quat. Sci. Rev., 24, 3-4, 307-322, doi: 10.1016/j.quascirev.2004.04.012.

Dombrádi E., Sokoutis D., Bada G., Cloetingh S., Horváth F., 2010: Modelling recent deformation of the Pannonian lithosphere: Lithospheric folding and tectonic topography. Tectonophysics, 484, 1-4, 103-118, doi: 10.1016/j.tecto.2009.09.014.

Farrell W. E., 1972: Deformation of the Earth by surface loads. Rev. Geophys., 10, 3, 761-797, doi: 10.1029/RG010i003p00761.

Fodor L., Bada G., Csillag G., Horváth E., Ruszkiczay-Rudiger Zs., Palotás K., Sikhegyi F., Timár G., Cloetingh S., Horváth F., 2005: An outline of neotectonic structures and morphotectonics of the western and central Pannonian Basin. Tectonophysics, 410, 1, 15-41, doi : 10.1016/j.tecto.2005.06.008.

Gebauer A., Kroner C., Jahr T., 2009: The influence of topographic and lithologic features on horizontal deformations. Geophys. J. Int., 177, 2, 586-602, doi: 10.1111/j.1365 $-246 \mathrm{X} .2009 .04072 . \mathrm{x}$.

Gebauer A., Steffen H., Kroner C., Jahr T., 2010: Finite element modelling of atmosphere loading effects on strain, tilt and displacement at multi-sensor stations. Geophys. J. Int., 181, 3, 1593-1612, doi: 10.1111/j.1365-246X.2010.04549.x.

Gráczer Z., Czifra T., Kiszely M., Mónus P., Zsíros T., 2012-2016: Hungarian National Seismological Bulletin 2011-2016 (Magyar Nemzeti Szeizmológiai Bulletin 20112016). Budapest: Kövesligethy Radó Szeizmologiai Obszervatórium, MTA CSFK GGI.

Grenerczy Gy., Kenyeres A., Fejes I., 2000: Present crustal movement and strain distribution in Central Europe inferred from GPS measurements. J. Geophys. Res., 105, B9, 21835-21846, doi: 10.1029/2000JB900127.

Grenerczy Gy., Sella G., Stein S., Kenyeres A., 2005: Tectonic implications of the GPS velocity field in the northern Adriatic region. Geophys. Res. Lett., 32, 16, L16311, doi : 10.1029/2005GL022947.

Gutenberg B., Richter F., 1942: Earthquake magnitude, intensity, energy and acceleration. Bull. Seismol. Soc. Am., 32, 3, 163-191.

Haas J. (Ed.), 2001: Geology of Hungary. Budapest: Eötvös University Press.

Hackl M., Malservisi R., Hugentobler U., Wonnacott R., 2011: Estimation of velocity uncertainties from GPS time series: Examples from the analysis of the South African TrigNet network. J. Geophys. Res., 116, B11404, doi: 10.1029/2010JB008142.

Hanssen R. F., 2001: Radar Interferometry: Data Interpretation and Error Analysis. Kluwer Academic Publishers, Dordrecht, pp. 328.

Harrison J. C., 1976: Cavity and topographic effects in tilt and strain measurements. J. Geophys. Res., 81, 2, 319-328, doi: 10.1029/JB081i002p00319. 
Horváth F., Cloetingh S., 1996: Stress-induced late stage subsidence anomalies in the Pannonian basin. Tectonophysics, 266, 1-4, 287-300, doi : 10.1016/S0040-1951(96) 00 194-1.

Kisházi P., Ivancsics J., 1985: Genetic petrology of the Sopron crystalline schist sequence. Acta Geol. Hung., 28, 3-4, 191-213.

Kontny B., Bosy J., Borkowski A., 2006: The use of permanent and epoch GPS coordinate time series in geodynamic investigations of Sudetes area - proposal of a new approch. Acta Geodyn. Geomater., 3, 3(143), 31-38.

Krásná H., Malkin Z., Böhm J., 2015: Non-linear VLBI station motions and their impact on the celestial reference frame and the Earth orientation parameters. J. Geod., 89, 10, 1019-1033, doi : 10.1007/s00190-015-0830-4.

Krásná H., Ros C. T., Pavetich P., Böhm J., Nilsson T., Schuh H., 2013: Investigation of crustal motion in Europe by analysing the European VLBI sessions. Acta Geod. Geophys., 48, 4, 389-404, doi: 10.1007/s40328-013-0034-4.

Kroner C., Jahr T., Kuhlmann S., Fischer K. D., 2005: Pressure induced noise on horizontal seismometer and strainmeter records evaluated by finite element modelling. Geophys. J. Int., 161, 1, 167-178, doi: 10.1111/j.1365-246X.2005.02576.x.

Massonnet D., Feigl K. L., 1998: Radar interferometry and its application to changes in the Earth's surface. Rev. Geophys., 36, 4, 441-500, doi: 10.1029/97RG03139.

Mentes Gy., 2000: Influence of Temperature and Barometric Pressure Variations on Extensometric Deformation Measurements at the Sopron Station. Acta Geod. Geophys. Hu., 35, 3, 277-282, doi : 10.1007/BF03325617.

Mentes Gy., 2010: Quartz tube extensometer for observation of Earth tides and local tectonic deformations at the Sopronbánfalva Geodynamic Observatory, Hungary. Rev. Sci. Instrum., 81, 7, 074501, doi: 10.1063/1.3470100.

Mentes Gy., 2012: Observation of local tectonic movements by a quartz-tube extensometer in the Sopronbanfalva Geodynamic Observatory, in Hungary - Validation of extensometric data by tidal analysis and simultaneous radon concentration measurements. J. Geodyn., 58, 38-43, doi: 10.1016/j.jog.2012.01.004.

Müller T., Zürn W., 1983: Observation of gravity changes during the passage of cold fronts. J. Geophys., 53, 155-162.

Olaiz A. J., Muñoz-Martín A., De Vicente G., Vegas R., Cloetingh S., 2009: European continuous active tectonic strain-stress map. Tectonophysics, 474, 1, 33-40, doi : $10.1016 /$ j.tecto 2008.06 .023 .

Onoue K., Takemoto S., 1998: Atmospheric pressure effect on ground strain observation at Donzurubo Observatory, Nara, Japan. In: Ducarme B., Paquet P., (Eds.), Proceedings of the 13th International Symposium on Earth Tides, Brussels: Observatoire royal de Belgique, pp. 157-164.

Pellegrinelli A., Perfetti N., Russo P., 2005: Time series analysis of daily solutions of IGFN permanent GPS stations. B. Geofis. Teor. Appl., 46, 2-3, 85-97.

Plank L., Böhm J., Schuh H., 2014: Precise station positions from VLBI observations to satellites: a simulation study. Journal of Geodesy, 88, 7, 659-673, doi: 10.1007/ s00190-014-0712-1. 
Rabbel W., Zschau J., 1985: Static deformations and gravity changes at the Earth's surface due to atmospheric loading. J. Geophys., 56, 81-99.

Rajner M., Liwosz T., 2017: Analysis of seasonal position variation for selected GNSS sites in Poland using loading modelling and GRACE data. Geod. Geodyn., 8, 4, 253-259, doi: 10.1016/j.geog.2017.04.001.

Salcher B. C., Meurers B., Smit J., Decker K., Hölzel M., Wagreich M., 2012: Strikeslip tectonics and Quaternary basin formation along the Vienna Basin fault system inferred from Bouguer gravity derivatives. Tectonics, 31, 3, TC3004, doi : 10.1029/ $2011 \mathrm{TC} 002979$.

Sánchez L., Völksen C., Sokolov A., Arenz H., Seitz F., 2018: Present-day surface deformation of the Alpine region inferred from geodetic techniques. Earth Syst. Sci. Data, 10, 1503-1526, doi: 10.5194/essd-10-1503-2018.

Sato T., Harrison J.C., 1990: Local effects on tidal strain measurements at Esashi, Japan. Geophys. J. Int., 102, 3, 513-526, doi: 10.1111/j.1365-246X.1990.tb04577.x.

Serpelloni E., Anzidei M., Baldi P., Casula G., Galvani A., 2005: Crustal velocity and strain-rate fields in Italy and surrounding regions: new results from the analysis of permanent and non-permanent GPS networks. Geophys. J. Int., 161, 3, 861-880, doi : 10.1111/j.1365-246X.2005.02618.x.

Síkhegyi F., 2002: Active Structural Evolution of the Western and Central Parts of the Pannonian Basin: a Geomorphological Approach, vol. 3. EGU Stephan Mueller Special Publication Series pp. 203-216.

Steffen H., Kuhlmann S., Jahr T., Kroner C., 2006: Numerical Modeling of the Barometric Pressure-Induced Noise in Horizontal Components for the Observatories Moxa and Schiltach. J. Geodyn., 41, 1-3, 242-252, doi : 10.1016/j.jog.2005.08.011.

Sternai P., Sue C., Husson L., Serpelloni E., Becker T. W., Willett S. D., Faccenna C., Di Giulio A., Spada G., Jolivet L., Valla P., Petit C., Nocquet J.-M., Walpersdorf A., Sébastien Castelltort S., 2019: Present-day uplift of the European Alps: Evaluating mechanisms and models of their relative contributions. Earth-Sci. Rev., 190, 589604, doi: 10.1016/j.earscirev.2019.01.005.

Sun H. P., Ducarme B., Dehant V., 1995: Effect of the atmospheric pressure on surface displacement. J. Geod., 70, 3, 131-139, doi: 10.1007/BF00943688.

Takemoto S., Lee M., Chen C.-Y., Kao M.-C., Mukai A., Ikawa T., Kuroda T., Abe T., 2006: Tidal strain observations in Chu-Chie, Taiwan. J. Geodyn., 41, 1-3, 198-204, doi : 10.1016/j.jog.2005.08.004.

Tesauro M., Hollenstein C., Egli R., Geiger A., Kahle H.-G., 2006: Analysis of central western Europe deformation using GPS and seismic data. J. Geodyn., 42, 4-5, 194-209, doi: 10.1016/j.jog.2006.08.001.

Tóth L., Mónus P., Bus Z., Györi E., 2008: Seismicity of the Pannonian Basin. In: Husebye E.S., eds) Earthquake Monitoring and Seismic Hazard Mitigation in Balkan Countries. NATO Science Series: IV: Earth and Environmental Sciences, Vol 81. Dordreht: Springer.

Tóth L., Mónus P., Zsíros T., Bondár I., Bus Z., Kosztyu Z., Kiszely M., Wéber Z., Czifra T. 1996-2018: Hungarian earthquake bulletin, 1995-2017. MTA GGKI és Georisk Kft, Budapest. 
Varga P., Varga T., 1994: Recent horizontal deformation in the Pannonian Basin measured with extensometers. Acta Geod. Geophys. Hu., 29, 1, 57-80.

Venedikov A. P., Arnoso J., Cai W., Vieira R., Tan S., Velez E. J., 2006: Separation of the long-term thermal effects from the strain measurements in the Geodynamics Laboratory of Lanzarote. J. Geodyn., 41, 1-3, 213-220, doi : 10.1016/j · jog. 2005.08.029.

Ward S. N., 1994: Constraints on the seismotectonics of the central Mediterranean from very long baseline interferometry. Geophys. J. Int., 117, 2, 441-452, doi: 10.1111/ j.1365-246X.1994.tb03943.x.

Wenzel H. G., 1996: The nanogal software: Earth tide data processing package ETERNA 3.30. Bulletin d'Information Marées Terrestres, 124, 9425-9439.

Zürn W., Exß J., Steffen H., Kroner C., Jahr T., Westerhaus M., 2007: On reduction of long-period horizontal seismic noise using local barometric pressure. Geophys. J. Int., 171, 2, 780-796, doi: 10.1111/j.1365-246X.2007.03553.x.

ZAMG, 2018: Austrian Earthquake Catalogue (AEC), Wien: Central Institute for Meteorology and Geodynamics (ZAMG), Geophysical Department. 